\title{
Using a Classroom Response System in an Introductory Business Statistics Course: Reflections and Lessons Learned
}

\author{
Meral (Demirbağ) Büyükkurt, Ying Li, and Robert Cassidy \\ Concordia University, Montreal, Quebec, Canada
}

\author{
mbuyukkurt@jmsb.concordia.ca rcassidy@alcor.concordia.ca \\ Iyin13@education.concordia.ca
}

\begin{abstract}
A Classroom Response System (CRS) was adopted in an introductory business statistics course for the first time. This paper reports on the reflections on this experience by the professor teaching this course and feedback and contributions of the other members of the research team. It begins by presenting a theoretical foundation for the use of CRS and proceeds to a rationale for its adoption in statistics courses. A detailed description of how CRS was used in this particular course is provided and lessons learned are discussed in light of the relevant research literature. We hope that our reflections and lessons learned will raise awareness among faculty members contemplating using CRS, especially those in introductory statistics, about issues that might be encountered the first time around and help them be more proactive in their initial use of CRS.
\end{abstract}

Keywords: Classroom Response Systems, clickers, peer discussion, introductory business statistics, educational technology, attitude toward statistics

\section{Introduction}

Traditional lecture-style instruction is ineffective in engaging students and fostering deep, longlasting learning (Bennett, Foreman-Peck \& Higgins, 1996; Gibbs \& Jenkins, 1992; Hake, 1998; Hesten, Wells \& Swackhammer, 1992), resulting in many graduates leaving university with inert knowledge - knowledge that cannot be activated to solve real problems (Grabinger \& Dunlap, 1995). Unfortunately, such mode of instruction remains predominant in colleges and universities. The limitations of traditional instruction are becoming ever more salient as the millennium students arrive in university. Growing up using the Internet and thriving on various social media, the "net generation" has developed what Frand (2000) terms "the information-age mindset." These students exhibit different preferences for learning than their predecessors, such as favoring teamwork, experiential and interactive learning, and learning with technology (Oblinger, 2003).

Material published as part of this publication, either on-line or in print, is copyrighted by the Informing Science Institute. Permission to make digital or paper copy of part or all of these works for personal or classroom use is granted without fee provided that the copies are not made or distributed for profit or commercial advantage AND that copies 1) bear this notice in full and 2) give the full citation on the first page. It is permissible to abstract these works so long as credit is given. To copy in all other cases or to republish or to post on a server or to redistribute to lists requires specific permission and payment of a fee. Contact Publisher@InformingScience.org to request redistribution permission.
In the context of introductory statistics where students are non-statistics majors, traditional lecturing is inadequate in addressing the widespread cognitive difficulties and unfavorable attitudes with respect to statistics learning (Fullerton \& Umphrey, 2001; Garfield \& Ahlgren, 1988; Waters, Martelli, Zakrajsek \& Popovich, 1998). On top of the inherent challenges with the subject matter, such as pervasive faulty intuitions in statistic 
thinking (Garfield \& Ahlgren, 1988), negative attitude toward statistics courses contributes further to poor examination performance (Tremblay, Gardner, \& Heipel, 2000; Wise, 1985). In the recent reform movement in teaching statistics, the realization of these issues has led to the advancement of a new pedagogy characterized by a paradigm shift from the information transmission model to a view of learning as active knowledge construction (Moore, 1997). Active learning strategies used to be difficult, if not impossible, to implement in large classrooms; however, with the development of educational technology, instructional tools such as Classroom Response Systems (CRSs) have made it much easier to create a more interactive, learner-centered learning environment. Studies on the use of CRS in statistics courses are also emerging (Koppel \& Berenson, 2009; Wit, 2003), although good practice and guiding pedagogical frameworks are not as developed as in some of the other disciplines, such as physics.

\section{Classroom Response Systems}

\section{What is a Classroom Response System?}

Classroom Response Systems (CRS), more commonly known as clickers, are electronic voting systems used in class for collating student responses to a given question (typically in multiplechoice format). It consists of a receiver, a software application, student input devices (handheld keypads), and an instructor remote control. Professor displays clicker questions that are either pre-inserted in lecture slides or created on the fly, activates voting and instructs students to answer the question. After voting is closed, a histogram showing students' aggregated responses can be instantly displayed on a projector screen. While the above description of CRS is the most commonly observed version, recently there are versions that accommodate numeric and textual answers as well.

\section{What Are the Affordances of CRS?}

Compared with alternative classroom feedback tools or techniques, such as flashcards or handraising, CRS has many advanced features. For example, it provides both anonymity and accountability (the results are anonymous to student peers but identifiable by the instructor through student clicker ID after the class). Anonymity, arguably, has contributed to the widely reported increased participation in class activities and positive attitude related to clicker use (Draper \& Brown, 2004; Freeman, Blayney, \& Ginns, 2006; Stowell \& Nelson, 2007). Moreover, clicker participation has been reported to be positively correlated with exam performance on questions targeting similar content (King \& Joshi, 2008).

CRS is also superior to hand-raising (or even flashcards) in obtaining honest student responses (Stowell \& Nelson, 2007), thus providing the instructor with more accurate feedback about students' state of knowledge. It was also found (Yourstone, Kraye, \& Albaum, 2008) that the instant feedback provided by CRS led to higher examination performance than delayed paper feedback for the same set of questions. Moreover, such feedback obtained at different points during a lecture can facilitate contingent teaching (Draper \& Brown, 2004), also known as agile teaching (Beatty, Leonard, Gerace, \& Dufresne, 2006), a teaching method in which the instructor adjusts the lecture to meet students' real-time needs instead of delivering strictly according to a lesson plan. In addition, the possibility of seeing other students' responses may raise student morale and motivation as they find that they are not the only one in their misunderstanding (Beatty, 2004).

\section{CRS and Principles for Learning Statistics}

CRS use has been well researched in physics teaching; effective pedagogies supported or enabled by this technology have been tested and instructional models such as Peer Instruction (Crouch \& 
Mazur, 2001; Crouch, Watkins, Fagen, \& Mazur, 2007; Mazur, 1997) and Question-Driven Instruction (Beatty \& Gerace, 2009; Beatty et al., 2006) developed. However, in many other disciplines including statistics, the use of CRS has not been explored as much.

Despite the scarcity of CRS research in undergraduate statistics courses, the appropriateness of CRS use in such a context can be established by linking the technical features of CRS and principles for learning statistics proposed by Garfield \& Ben-Zvi (2007, pp. 387-389), which are listed below:

1. Students learn by constructing knowledge

2. Students learn by active involvement in learning activities

3. Students learn to do well only what they practice doing

4. It is easy to underestimate the difficulty students have in understanding basic concepts of probability and statistics

5. It is easy to overestimate how well students understand basic concepts

6. Learning is enhanced by having students become aware of and confront their errors in reasoning

7. Technological tools should be used to help students visualize and explore data, not just to follow algorithms to pre-determined ends

8. Students learn better if they receive consistent and helpful feedback on their performance

Used effectively, CRS can be argued to support the practicing of all of the above principles for learning statistics except for principle 7, which is irrelevant to the issue at hand. CRS can address Principle 4 and 5 since the graphical display of students' aggregated responses provide feedback to the professor who can then accurately assess students' knowledge level objectively without guesswork. The same instant feedback can also bring students face-to-face with their problematic reasoning (Principle 6 and 8) provided that clicker questions are designed to reflect common student misconceptions and other cognitive difficulties, and such errors in reasoning are immediately discussed. In a similar vein, CRS has the potential to facilitate Principle 1, 2, and 3 when it is used to encourage active learning practices such as case studies (Herreid, 2006) and peer discussion (Lucas, 2009) and provide ample opportunities for students to practice and apply what they learn in different contexts (Reay, Li \& Bao, 2008).

\section{Implementation of CRS in an Introductory Business Statistics Course}

\section{Background}

The reported experience with CRS is from an Introductory Business Statistics course in a Canadian university where it is a required course for all business students regardless of their majors. The coordinated course had eight sections of which the professor on our research team (the first author of this paper) taught two, with 118 students in each section. CRS was used in both of these sections but not in the remaining six sections.

The professor had returned to teaching Introductory Statistics the previous semester following 15 years of teaching upper-level courses. She was surprised by the particular challenges this introductory statistics course presented. Echoing the negative attitudes identified in the preceding literature review, past students' comments about the course such as "difficult subject", "boring lectures", "useless for any business major" and those about the best study strategy such as "solve as many problems as you can", "take "problem solving marathons" at outside-school companies" were very prevalent. In her first semester, she observed how these unproductive attitudes turned 
into inattention and disruptive behaviors in class and caused major classroom management issues. As suggested by Garfield (1995), the professor decided to incorporate attitude goals into her goals for the course, which are listed below:

1) to reverse the students' negative perceptions about the usefulness of statistics

2) to change their focus from memorizing problem solutions to understanding statistics

3) to get their attention in class

4) to improve the management of the students' in-class behavior

\section{Decision to Adopt CRS}

In the previous semester, the professor used CRS on a trial basis for two weeks and was impressed by the attention it received. Given the widely reported benefits and potentials of using CRS in the literature (Beatty, 2004; Caldwell, 2007), the support offered by the Centre for Teaching and Learning Services (CTLS) and the professors' own experience with the trial, she decided to adopt CRS for the entire semester to help her change students' negative perception of statistics and achieve her course goals.

She sent an e-mail to the students registered in these sections announcing that they would be using CRS and giving instructions to purchase it and register it online. Furthermore, the reasons for using CRS and the potential benefits associated with its use were communicated to the students in the course outline, during the first class of the semester and in a PowerPoint file created by the CRS manufacturer $\mathrm{i}>$ clicker. The students were given the option of switching to another section if they did not wish to use clickers.

\section{How CRS Was Used}

In a 75-minute class, three to five clicker questions were presented, interspersed with mini lectures. The sequence of steps followed during each class period was:

1. The professor presented a multiple-choice question in PowerPoint after lecturing on a statistics concept

2. The professor instructed the students to discuss their answers with at least 2-3 other students sitting around them

3. After a minute or so, the professor announced the end of voting

4. A summary graph of the answers was displayed

5. If the distribution of responses indicated that the majority of the students did not understand the concept, the professor gave further explanations and answered any questions.

Four percent of the grade was distributed to participation in answering CRS questions regardless of the correctness of responses. Based on student request, these questions were also used for review purposes before examinations where students responded individually with no peer discussion.

\section{Observations, Survey Data and Reflections}

Professor's observation of the students' in-class learning throughout the semester, the results of a survey of the students and the reflections of the professor on the experience of using clickers are discussed below as lessons learned from the first experience with CRS. 


\section{Lesson 1: CRS is Effective in Improving Behavioral Engagement}

Since this was a fall semester, the majority of students in the class were new to the university and to CRS. The professor created questions based on her knowledge of students' misconceptions about statistics. The responses received were as the professor expected; misconceptions were discussed each time and clarifications were presented to the students. An animated class discussion followed the vote on each question. Students seemed more in tune with the class learning activities and thus less frequently engaged in disruptive behaviors.

Returning to the lecture following a clicker question was sometimes challenging. Some students carried on with their discussions, while others started discussing unrelated topics. While it was a frustrating experience for both the professor and some of the students, it was manageable. A bell proved to be quite effective.

Since this technology was new to the professor as well, some technical difficulties were experienced in class. Difficulties experienced were 1) registration online, 2) lending students a CRS unit per class when they forgot to bring theirs to class; 3) managing the files the specific CRS created at the end of the semester (deleting records of students who dropped the course, identifying unregistered students/CRS units). It should be noted that these technical difficulties have not been experienced since this first semester mostly due to upgrades of the software used.

Given that increasing students' attention was one of the main reasons the professor chose to use CRS, and this goal was satisfactorily achieved, she decided to continue using the system while improving upon this semester's experience.

\section{Lesson 2: Students Will Benefit from CRS If They Prepare for Class}

Almost every class, students were reminded of the importance of at least skimming through the chapter and reviewing the lecture outline posted in the FirstClass course folder, the majority did not do this consistently which resulted in random answer selection to get the participation mark. The students who prepared for class and engaged in answering the questions were finding the experience very positive. Others found it a nuisance since it "required" them to attend classes.

Studies on reading compliance among college students reveal that only $20-30 \%$ of college students complete their reading assignments on any given day (Hobson, 2004). Poor class preparation constitutes an even more compelling issue when CRS-based instruction is used. Research indicates that poor preparation for class is one of the reasons for students' reluctance to engage in peer discussion during clicker use (Hoekstra, 2008). Mirroring the above studies, the professor in the current study observed that, "mindless clicking" to get the participation mark seems to be a short-cut for some students who wished not to prepare for class. Although more effective and frequent explanation of CRS benefits will help engage students more in clicker-based activities, an effective method of getting students to prepare for each class is needed to transform CRS use into a mindful exercise in learning. Possible options that will be considered are a pre-class quiz to check that the reading has been done, an online weekly log of reading, clicker use and reflections on learning.

In addition to a lack of preparation, another suspected reason for "mindless clicking" is the CRS participation reward system. Students earned participation marks if they answered at least $75 \%$ of the clicker questions in a session. Whether they answered the question correctly did not have an impact on their participation mark. It is possible that some students "mindlessly clicked" without even trying to answer the questions correctly. While keeping in mind the detrimental effect of frequent, high-stakes grading on the quality of student discourse and learning (James, 2006; James, Barbieri \& Garcia, 2008; Willoughby \& Gustafson, 2009), assigning a small amount of 
credit to correct answers will motivate students to really think about the questions and process relevant information at a deeper level. This could be another way to reduce mindless clicking.

\section{Lesson 3: The Benefits of CRS use Is Not Self-Explanatory; Effectively Communicate the Benefits to the Students}

Consistent with in-class observations, results from two student surveys indicate mixed perceptions about the value of CRS use. The ratio of positive to negative comments about CRS experience received from students on teaching evaluations were 1 to 2 . Some of the negative responses, such as "leaves less time for lectures", "questions are not similar to exam questions" indicated that the students had not clearly understood the purpose of using CRS. Others, such as "not helpful", "useless" indicated that students did not perceive its contribution to their learning. Among the positive comments, some such as "effective", "facilitates learning", "helpful in learning" showed that at least some students appreciated its value.

A short clicker survey of five items provided by the CTLS was administered on paper in class near the end of the semester. The first four items measured the impact of CRS use on students' perceived motivation to attend class, sustained interest in class, motivation to prepare for class, and the learning of course material, respectively. The last item solicited students' overall impression of the usefulness of CRS use. The percentages of agreement for the first four items are presented in Table 1. The results of the last item are presented in Table 2.

As the two tables show, more than half of the students perceived clickers to be useful overall $(65 \%)$, and slightly more than half of the students believed that clickers help sustain their attention $(55 \%)$ and learn the course material (52\%). Where CRS use in this course particularly failed was in increasing students' intrinsic motivation to attend class and to prepare for class, with the latter representing a strikingly small number of people (7\%).

Despite the mixed reception received, students requested to answer the clicker questions as a review to prepare for each exam indicating they were beginning to appreciate their value.

The professor's observations and student survey data both suggested that many students did not understand the benefits of clicker questions. Contribution of clicker questions to their understanding of the course subject and their performance in the course needs to be communicated to the students effectively. This concern is validated by relevant literature on similar challenges in getting students to accept a new way of learning that comes with CRS use (Hoekstra, 2008; Trees \& Jackson, 2007) and on the need for explaining the benefits of using CRS in order to "frame student perceptions of the technology" (Trees \& Jackson, 2007, p. 38). Such explanation is termed "metacommunication" by Beatty (2004), who argues that articulating the rationale behind instructional decisions is the most influential factor in shaping student attitudes toward educational innovation. Metacommunication seems to be a potentially good solution to students' lack of learning engagement as manifested in both mindless participation in clicker questions and poor preparation for class. 
Table 1. Student Perception of Clicker Benefits

\begin{tabular}{lc} 
Item & $\begin{array}{c}\text { Percent } \\
\text { Agreement (\#) }\end{array}$ \\
\hline The use of clickers is increasing my desire to come to class. & $35 \%(57)$ \\
The use of clickers is helping me to stay interested during class time. & $55 \%(89)$ \\
The use of clickers is motivating me to spend more time preparing for class. & $7 \%(11)$ \\
The use of clickers is helping me learn the course material. & $52 \%(84)$
\end{tabular}

Note: $\mathrm{N}=162$. Agreement is defined as a response of "agree" or "strongly agree". Other responses included "neither agree nor disagree", "disagree" and "strongly disagree".

Table 2. Student Overall Impression

\begin{tabular}{lc} 
Which statement best reflects your OVERALL IMPRESSION of clickers? & Percent (\#) \\
\hline Very Useful & $14 \%(23)$ \\
Somewhat Useful & $51 \%(82)$ \\
Not useful but also not a waste of time & $13 \%(22)$ \\
Somewhat a waste of time and resources & $15 \%(24)$ \\
Complete waste of time and resources & $7 \%(11)$ \\
\hline
\end{tabular}

Note: $\mathrm{N}=162$. Agreement is defined as a response of "agree" or "strongly agree". Other responses included "neither agree nor disagree", "disagree" and "strongly disagree".

\section{Conclusion and Suggestions for Future Research}

In this paper, we discussed issues related to CRS use based on one professor's initial experience with using the technology in her classes. Lessons were drawn from professor's observations and reflections and surveys of students. CRS use proved to be effective in helping the professor achieve her goals of increasing attention and reducing distractions in class. It was also perceived by the majority of students as useful. However, this first implementation also revealed a few areas in need of improvement, such as students' lack of cognitive engagement during clicker question sessions, students' insufficient preparation for class and technical glitches. Lessons learned were discussed in light of the current CRS research literature in the hope of providing a more valid reference for professors interested in using CRS in their own teaching. By joining those who endorse "the idea of making teaching practices public, sharable, and subject to analysis and experimentation" (Bransford, Brophy \& Williams, 2000, p. 81), this paper represents our commitment to the scholarship of teaching in higher education. Future research into various methods of increasing students' engagement in in-class learning as well as effectively communicating the benefits of CRS use to the students is currently underway. 


\section{References}

Beatty, I. (2004). Transforming student learning with classroom communication systems. Retrieved from http://net.educause.edu/ir/library/pdf/ERB0403.pdf

Beatty, I. D., \& Gerace, W. J. (2009). Technology-enhanced formative assessment: A research-based pedagogy for teaching science with classroom response technology. Journal of Science Education \& Technology, 18, 146-162.

Beatty, I. D., Leonard, W. J., Gerace, W. J., \& Dufresne, R. J. (2006). Question driven instruction: Teaching science (well) with an audience response system. In D. A. Banks (Ed.), Audience response systems in higher education: Applications and cases (pp. 96-115). Hershey, PA: Information Science Publishing.

Bennett, C., Foreman-Peck, L., \& Higgins, C. (1996). Researching into teaching methods in colleges and universities. London: Kogan Page.

Bransford, J., Brophy, S., \& Williams, S. (2000). When computer technologies meet the learning sciences: issues and opportunities. Journal of Applied Developmental Psychology, 21(1), 59-84.

Caldwell, J. E. (2007). Clickers in the large classroom: Current research and best-practice tips. Life Sciences Education, 6(1), 9-20.

Crouch, C. H., \& Mazur, E. (2001). Peer instruction: Ten years of experience and results. American Journal of Physics, 69(9), 970-977.

Crouch, C. H., Watkins, J., Fagen, A. P., \& Mazur, E. (2007). Peer instruction: Engaging students one-onone, all at once. Retrieved from http://www.compadre.org/Repository/document/ServeFile.cfm?DocID=241\&ID=4990

Draper, S. W., \& Brown, M. I. (2004). Increasing interactivity in lectures using an electronic voting system. Journal of Computer Assisted Learning, 20(2), 81-94

Frand, J. L. (2000). The Information-Age mindset. EDUCAUSE Review, 35(5), 14-20.

Freeman, M., Blayney, P., \& Ginns, P. (2006). Anonymity and in class learning: The case for electronic response systems. Australasian Journal of Educational Technology, 22(4), 568-580.

Fullerton, J. A., \& Umphrey, D. (2001). An analysis of attitudes toward statistics: Gender differences among advertising majors. Paper presented at the Annual Meeting of the Association for Education in Journalism and Mass Communication, Washington, DC.

Garfield, J. (1995). How students learn statistics. International Statistics Review, 63(1), 25-34.

Garfield, J., \& Ahlgren, A. (1988). Difficulties in learning basic concepts in probability and statistics: implications for research. Journal for Research in Mathematics Education, 19(1), 44-63.

Garfield, J., \& Ben-Zvi, D. (2007). How students learn statistics revisited: A current review of research on teaching and learning statistics. International Statistical Review, 75(3), 372-396.

Gibbs, G., \& Jenkins, A. (1992). Teaching large classes in higher education: How to maintain quality with reduced resources. London: Kogan Page.

Grabinger, R. S., \& Dunlap, J. C. (1995). Rich environments for active learning: A definition. Association for Learning Technology Journal, 3(2), 5-34.

Hake, R. (1998). Interactive-engagement versus traditional methods: A six-thousand student survey of mechanics test data for introductory physics courses. American Journal of Physics, 66, 64-74.

Hestenes, D., Wells, M., \& Swackhammer, G. (1992). Force concept inventory. The Physics Teacher, $30(3), 141-158$.

Herreid, C. F. (2006) "Clicker'” cases: Introducing case study teaching into large classrooms. Journal of College Science Teaching, 36(2), 43-47 
Hobson, E. H. (2004). Getting students to read: Fourteen tips. IDEA Paper, 40, 1-6. Retrieved from http://www.theideacenter.org/sites/default/files/Idea_Paper_40.pdf

Hoekstra, A. (2008). Vibrant student voices: Exploring effects of the use of clickers in large college courses. Learning, Media, \& Technology, 33(4), 329-341.

James, M. C. (2006). The effect of grading incentive on student discourse in peer instruction. American Journal of Physics, 74(8), 689-691.

James, M. C., Barbieri, F., \& Garcia, P. (2008). What are they talking about? Lessons learned from a study of peer instruction. Astronomy Education Review, 7(1).

King, D. B., \& Joshi, S. (2008). Gender differences in the use and effectiveness of personal response devices. Journal of Science Education and Technology, 17(6), 544-552.

Koppel, N., \& Berenson, M. (2009). Ask the audience - Using clickers to enhance introductory business statistics courses. Information Systems Education Journal, 7(92), 1-18.

Lucas, A. (2009). Using peer instruction and i-clickers to enhance student participation in Calculus. Primus, 19(3), 219-231.

Mazur, E. (1997). Peer instruction: A user's manual. Englewood Cliffs, N. J.: Prentice Hall.

Moore, D. S. (1997). New pedagogy and new content: The case of statistics. International Statistical Review, 65(2), 123-165.

Oblinger, D. G. (2003). Boomers \& gen-Xers, millennials: Understanding the "new students". EDUCAUSE Review, 38(4), 37-47.

Reay, N. W., Li, P., \& Bao, L. (2008). Testing a new voting machine question methodology. American Journal of Physics, 76(2).

Stowell, J. R., \& Nelson, J. M. (2007). Benefits of electronic audience response systems on student participation, learning, and emotion. Teaching of Psychology, 34, 253-258.

Trees, A. R., \& Jackson, M. H. (2007). The learning environment in clicker classrooms: Student processes of learning and involvement in large university-level courses using student response systems. Learning, Media and Technology, 32(1), 21-40.

Tremblay, P. F., Gardner, R. C., \& Heipel, G. (2000). A model of the relationship among measures of affect, aptitude, and performance in introductory statistics. Canadian Journal of Behavioural Science, $32(1), 40-48$.

Waters, L. K., Martelli, T. A., Zakrajsek, T., \& Popovich, P. M. (1998). Attitudes toward statistics: An evaluation of multiple measures. Educational and Psychological Measurement, 48, 513-516.

Willoughby, S. D., \& Gustafson, E. (2009). Technology talks: Clickers and grading incentive in the large lecture hall. American Journal of Physics, 77(2), 180-183.

Wise, S. L. (1985). The development and validation of a scale measuring attitudes toward statistics. Educational and Psychological Measurement, 45, 401-405.

Wit, E. (2003). Who wants to be...The use of a personal response system in statistics teaching. MSOR Connections, 3(2), 14-20.

Yourstone, S. A., Kraye, H. S., \& Albaum, G. (2008). Classroom questioning with immediate electronic response: Do clickers improve learning? Decision Sciences Journal of Innovative Education, 6(1), 7588. 


\section{Biographies}

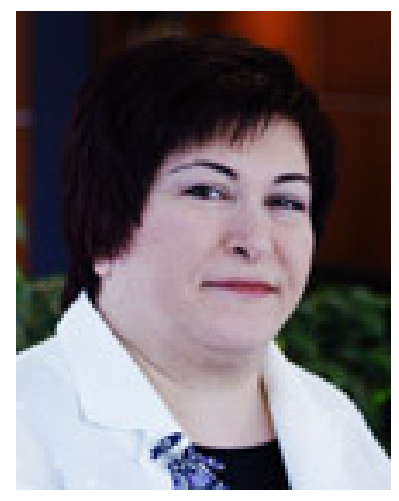

Dr. Meral (Demirbağ) Büyükkurt obtained her BA in Accounting and Finance from Bogazici University (Turkey), her MBA and $\mathrm{PhD}$ in Business with a major in Decision Sciences and minors in MIS and Statistics from Indiana University. She was a visiting assistant professor at Washington State University, visiting scholar at Indiana University, visiting associate professor at Koç University (Turkey), and participated in the development of the curriculum model for the School of Management of Sabanci University (Turkey). She teaches Information Systems Analysis and Introductory Statistics. Her current research focuses on information technology use in teaching statistics.

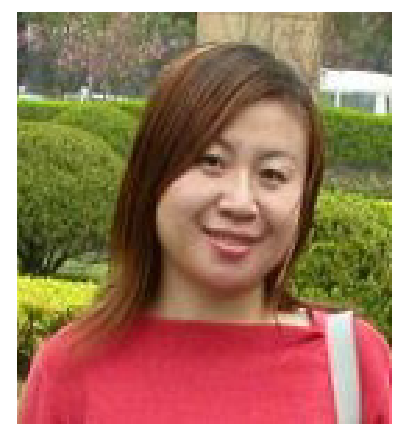

Ms. Ying Li is a part-time faculty member in the Education Department of Concordia University. She obtained her MA in Education Technology from Concordia University in 2011 and her MA in Applied Linguistics from China Maritime University in 2001.

Ms. Ying Li has been engaged in research work on clicker use since 2009 when she was employed by the Centre for Teaching and Learning Services (CTLS) at Concordia University as research assistant. She conducted clicker perception surveys of students and interviews with faculty members to investigate implementation details, perceived benefits and issues associated with clicker use. She created the clicker content of the CTLS website providing guidelines and resources for faculty members. Apart from teaching and research, Ying Li is also working as instructional designer for Veterans Affairs Canada.

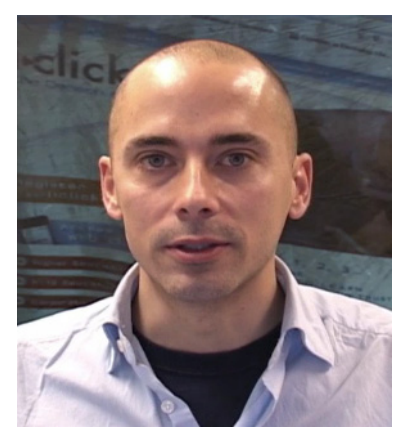

Dr. Robert Cassidy obtained his BS in Biology and $\mathrm{PhD}$ in Neuroscience from Georgetown University. He is a visiting assistant professor at Concordia University where he teaches various undergraduate courses in psychology. His current research focuses on higher education as a well as moral cognition. 